\title{
Does Slower Monetary Expansion Discriminate Against Housing?
}

T HE "Declaration of National Housing Policy" in the Housing Act of 1949 establishes as one of the national objectives "the realization as soon as feasible of the goal of a decent home and suitable living environment for every American family"; and it requires programs "to encourage and assist . . . the stabilization of the housing industry at a high volume of residential construction". In view of the importance of housing, there is a natural hesitancy on the part of any policy maker to take actions which he considers to be detrimental to the housing industry.

In our complex society it is difficult to determine which policies are detrimental to the housing situam tion, and there are few standards for judging to what extent other desirable objectives should be subordinated to achieve this one. ${ }^{1}$ This study is an investigation of the extent to which the residential construction industry is affected by a shift from rapid monetary expansion to a more moderate rate of monetary growth. The study presents and examines the evidence frequently cited as bearing on the ques. tion of whether the housing sector should act as a constraint in the formulation of monetary policy designed for the general welfare.

\section{Thecont Economic Developments}

Total demand for goods and services (gross national product) has been excessive since last sum-

\footnotetext{
The Employment Act of 1946 requires the Government to initiate policies "to promote maximum employment, production, and purchasing power".
}

mer, adding to inflationary pressures. Since the third quarter of 1967, total demand has gone up at over a 9 per cent anmual rate. By comparison, the upward trend growth in spending since 1957 has been about 6 per cent per year, and the increase in productive capacity has been at an estimated 4 per cent rate. Reflecting the strong demands, overall prices have risen at a 4 per cent rate since last summer, about double the trend rate since 1957 .

Despite the rapid growth in total demand, the increasing upward pressures on prices, and a resulting deterioration in the nation's balance of payments with the rest of the world, monetary growth continued at a rapid rate. In the ten months ended November 1967, the money supply rose at a 7.7 per cent annual rate, the fastest rate of increase over any ten-month period since 1948. Since November money has risen at about a 5.7 per cent mate, faster than 90 per cent of the six-month periods. By com parison, the trend growth in money supply was 2.4 per cent per year from 1957 to 1966.

One reason that sharp monetary expansion was not abated last fall and winter was a fear that monetary restraint would bear heavily and inequitably on the housing sector. As early as the July 18, 1967, meeting of the Federal Open Market Committee, a reason cited in the published record of the policy actions for not moving toward monetary restraint was "that any significant further increases in market interest rates might reduce the flows of funds into mortgages and slow the recovery under way in residential con- 
struction activity". According to the published record, similar sentiments have been expressed or implied at other meetings.

The economic problem facing the nation since last summer has been one of excessive total demands for goods and services. According to traditional views, monetary actions should be designed with the objective of reducing these demands to the extent necessary to attain price stability while continuing to achieve relatively full utilization of resources. In reducing total demands, the demand for housing also will be affected. The issue is whether the burden of the cutbacks falls particularly heavily or inequitably on this industry.

\section{Monerery Poriods}

Some insight into the effect of monetary actions on residential construction can be obtained from a review of periods in our recent history when monetary actions were relatively less expansive. Rates of growth in the money supply (demand deposits plus currency) are used in this phase of the study as a measure of monetary expansion."2

Chart I plots the money stack since 1951. The shaded areas are periods of relatively slow (or negative) money growth. The fastest rate of growth of

2Constructing periods on the basis of unadjusted market interest rates would give much different results. It is not clear, however, that a more sophisticated interest rate study which includes an analysis of changing inflationary expectations, methods of Government finance, and other forces influencing the demand for credit would give a significantly different picture.

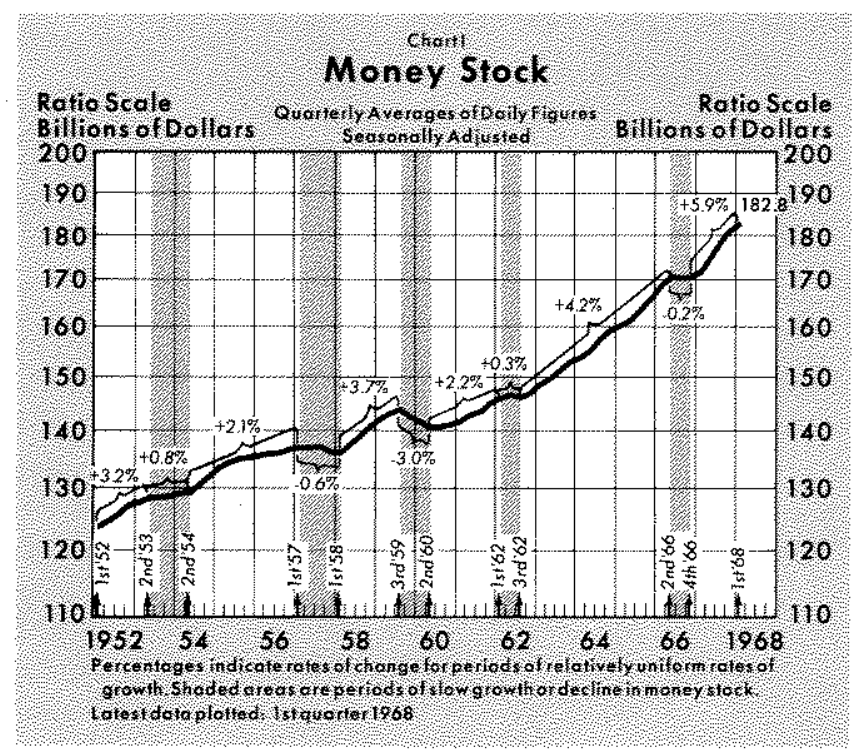

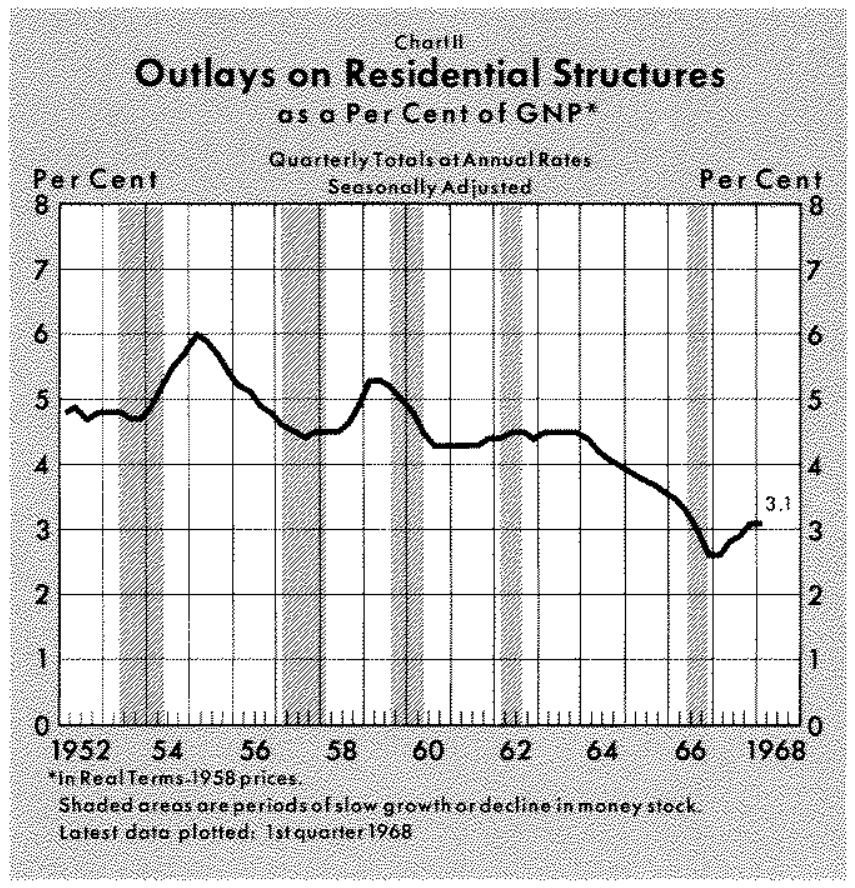

the money supply during these slow growth periods was an 0.8 per cent annual rate, whereas the average growth over the entire 1951-1967 period was at a 2.3 per cent rate. Throughout the rest of this article these periods are considered to be ones of monetary restraint and are denoted on the charts by shading.

\section{Slow Monewy Growh and \\ Tesidential Construction}

Comparison of expenditures on housing relative to total spending indicates that relatively slow rates of monetary growth do not cause excessive cutbacks in spending for homes. Chart II shows outlays on residential construction as a per cent of gross national product in real terms since 1951. In this period the housing sector has begun a prolonged decline relative to other sectors on three occasions. An interesting aspect of the chart is that each of these three instances was during a period of monetary expansion. During the first three to six months of a period of slow monetary expansion, the housing sector has tended to continue its relative decline begun during a previous period of monetary expansion; ${ }^{3}$ but then as monetary restraint continued, housing tended to level off or start rising relative to other activities. The one exception was the $1959-1960$ period.

\footnotetext{
3The decline was particularly sharp in the early months of the 1966 monetary restraint period, when Govemment regulations caused a marked reduction in the flow of funds into mortgages. A discussion of these market interferences is presented later.
} 
The number of new, private, nonfarm houses started each quarter (Chart III) has followed a similar pattern. All marked and sustained declines in housing starts began in periods of monetary expansion. In several cases the decline in starts was reversed after three to six months of monetary restraint, and the number of housing starts actually increased.

One reason a traditional view has developed that a relatively slow growth of money damages the housing industry is a belief that high interest rates indicate monetary restraint. However, the facts do not bear out this association, as an article in the November 1967 issue of this Review pointed out.

An examination of recent history indicates that rapid expansion in bank credit and money has resulted, after a brief lag, in excessive demands for goods and services, higher prices, and hence, rising interest rates. A slowdown in monetary growth imposed during an inflationary period has temporarily reinforced upward pressures on interest rates as the supply of credit was reduced. After about four months, however, when monetary actions have become effective in reducing aggregate spending and inflationary expectations, the demand for credit also has fallen. Entrepreneurs' demands for investment were lessened not only because of the lower overall demand, but due to reduced pressures to buy goods today to get a cheaper price. Contraction in the demand for credit has caused interest rates to fall. Mortgage interest rates have behaved in roughly

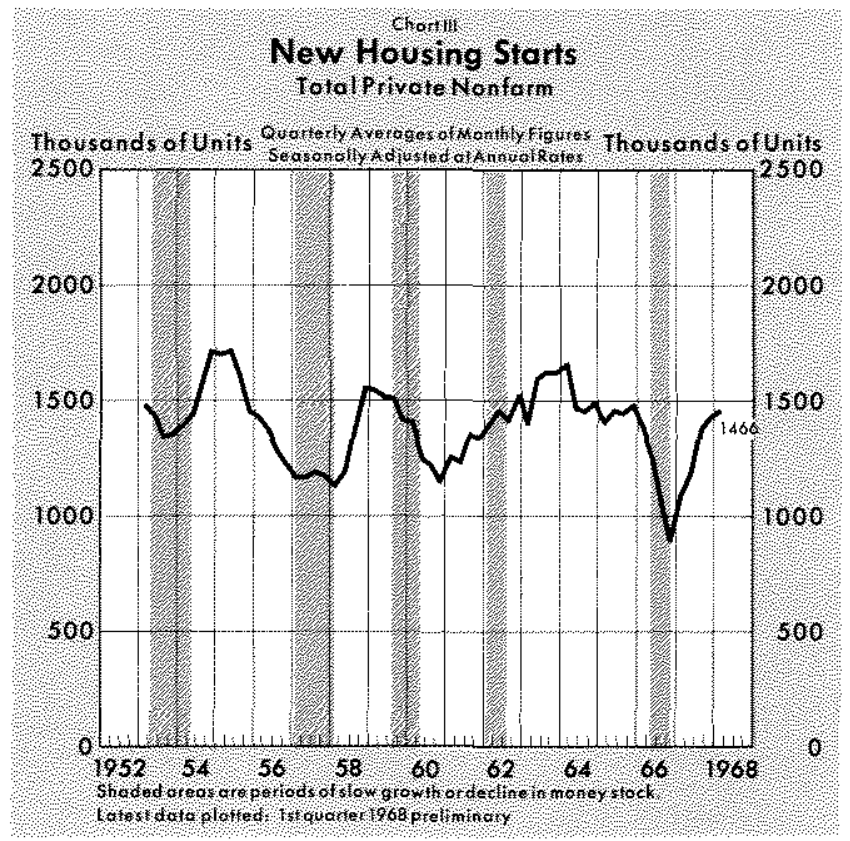

the same manner as other interest rates ${ }^{4}$.

In a study by Leonall Andersen on "The Incidence of Monetary and Fiscal Measures on the Structure of Output", "the following interest rate elasticities for the residential housing industry and other major sectors of investment were found:

\begin{tabular}{|c|c|c|}
\hline \multicolumn{3}{|c|}{$\begin{array}{l}\text { Elasticities of Equilibrium Output With Respect } \\
\text { To Income and Interest Rates Elastics }\end{array}$} \\
\hline INDUSTRY & IMCOME & INTERES \\
\hline \multicolumn{3}{|l|}{ Construction } \\
\hline State and local & .86 & -.06 \\
\hline 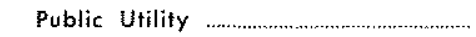 & 1.03 & -.25 \\
\hline Commercial & 1.21 & -.27 \\
\hline Indusirial & 1.34 & -.24 \\
\hline 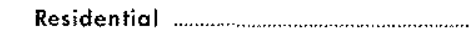 & 1.72 & $=.29$ \\
\hline \multicolumn{3}{|l|}{ Plont Equipment } \\
\hline Producer Durables & 1.20 &. .17 \\
\hline Farm Equipment & 1,14 &. .79 \\
\hline Aufomobiles & 1.66 & -.26 \\
\hline
\end{tabular}

These results demonstrate that a rise in interest rates has affected home building more than most other activities. The responsiveness of housing to in-

tThe following regression indicates that during the 1960 1967 period conventional mortgage rates have been negatively related to a three-month period of monetary restraint, but positively related during ten-month periods.

Monetary restraint was considered to be an annual growth rate of less than 2.6 per cent (the trend over the 1957-1967 period). At this rate money would grow 0.6 per cent over three months, and 2.4 per cent over ten months. Assuming that this rate of growth is neutral, a negative regression coefficient implies a reverse relationship between money growth and mortgage interest rates, and a positive coefficient suggests that rates move in the same direction as money's movement around the neutral rate of growth. These assumptions are incorporated in the definitions of $\mathrm{M}_{3}^{*}$ and $\mathrm{M}^{*} 10$.

$i_{t}=$ National average of the average monthly confract interest rates on conventional mortgages on new homes made by savings and loans.

$m_{t}=$ Monthly average of seasonally adjusted private demand deposits plus curreney in the hands of the public.

The equation estimated was:

$i_{\mathrm{E}}=a_{0}+a_{1} i_{t-1}+a_{2} M^{*}{ }_{3}+a_{3} M^{*}{ }_{10}$

Where: $\quad M^{*}{ }_{3}=\frac{M_{t}-1.006 M_{t-3}}{M_{t-3}}$

The results were:

$$
\mathrm{M}_{10}^{*}=\frac{\mathrm{M}_{\mathrm{t}}-1,024 \mathrm{M}_{\mathrm{t}-10}}{\mathrm{M}_{\mathrm{t}-10}}
$$

$$
\begin{aligned}
& \mathrm{i}_{\mathrm{t}}=-.0003+1.001 \mathrm{i}_{\mathrm{t}-1}-\frac{2.318 \mathrm{M}^{*} \mathrm{~s}+1.54 \mathrm{M}^{*}{ }_{10}}{(.002)} \\
& \frac{\text { Standard Error of Estimate }}{\text { Mean of } \mathrm{i}_{\mathrm{t}}}=\frac{0.03}{5.30}=.006
\end{aligned}
$$

All variables were significant at the 1 per cent level.

5 Andersen, Leonall, The Review of Economics and Statistics, August 3 , 1964, Harvard University, Boston, pp. 260-268. 
terest rates results in large part because financing normally represents a large proportion of total costs. Now, Charts II and III are more understandable. Rising interest rates, which usually accompany prolonged periods of monetary expansion, act as a deterrent to housing. The damaging effect might be continued temporarily by initial upward pressures on interest rates resulting from a more restrictive monetary action, but the falling rates resulting from the over-all effect of a more moderate growth in money are a powerful stimulus to the housing sector.

Interest rates are not the only factor affecting housing demand, and its responsiveness to interest rates probably changes as people's expectations of a "normal" or future interest rate change. If, for example, rates remained at a high level for an extended period, increasing demand might result as the "normal" rate gradually shifted upward. This partially explains how a spurt in housing could develop in early 1967 when mortgage rates were at a high level. Although long-term rates were relatively high, they were slightly lower than those in the immediately preceding period, which probably weighs heaviest on peoples expectations.

Although changes in market interest rates do bear heavily on residential construction, much of the im-

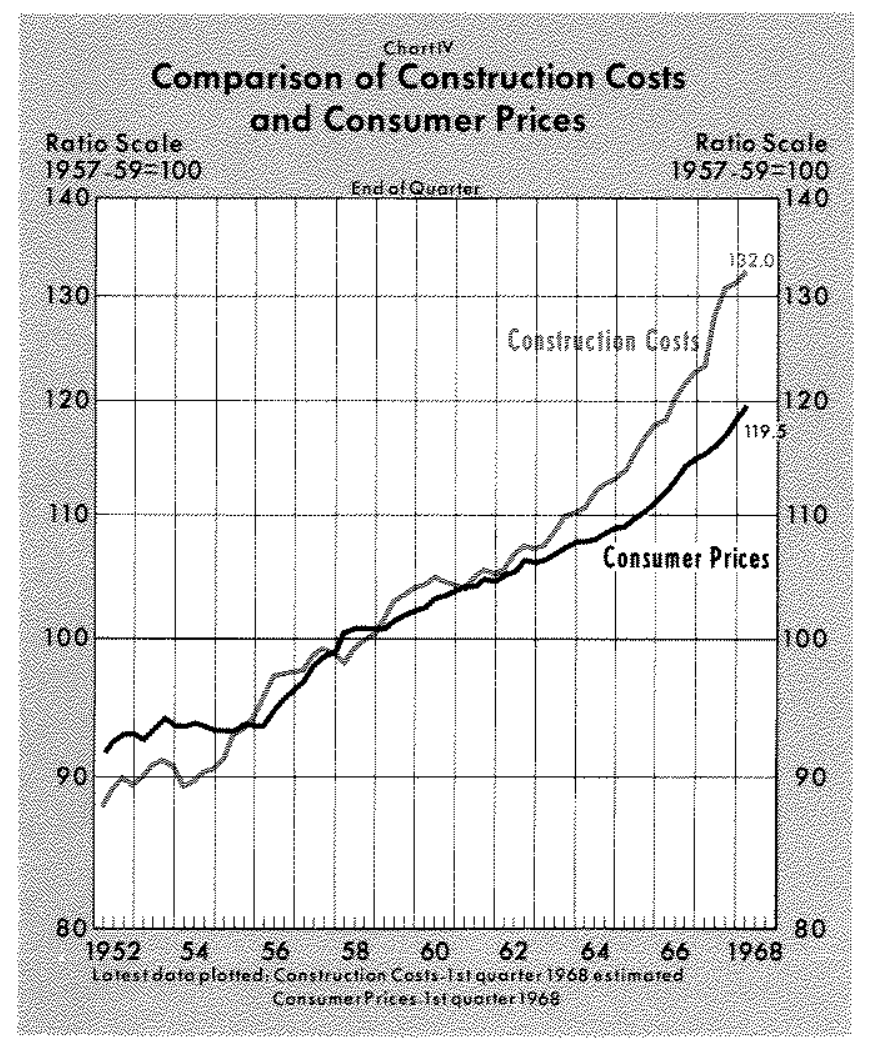

pact flows from the unavailability of funds caused by interferences to the market process rather than the higher rates, per se. Many obstructions to real estate financing result from Governmental laws, regulations, and practices, while others reflect institutional rigidities.

One example of market interference is the usury laws which in some areas may prohibit interest rates on mortgages from rising to the going market rate. Another such interference is Regulation $Q$ and other rate regulations on financial intermediaries, making these institutions, which lend heavily on real estate, less competitive than big businesses and Government in obtaining funds during periods of relatively high market rates. Another practice discriminating against real estate financing is administrative pressure on Federal Home Loan Banks at times of money market tightness to restrain their borrowing and relending to savings and loan associations. Another is the rigidity of contract rates on FHA and VA loans, with the accompanying discriminating "point" discounting system of mortgage financing.

\section{Altematwes to Slower Monetany Expansion}

Inflation, an alternative to proper monetary restraint, not only hurts the housing industry by increasing the cost of financing, but it raises the costs of building a house. ${ }^{6}$ According to data published by the U. S. Department of Housing and Urban Development for twenty major pricing areas of the country, the labor and materials cost of constructing a selected sample of brick and frame houses rose at a 4.2 per cent annual rate from 1963 to 1967 (Chart IV). Some of the rise in costs may have reflected a bidding away of men and materials for the war effort, but about two-thirds of this increase can be attributed to a general inflationary price rise. The increase in the price of homes between 1963 and 1967 resulted in 13.5 per cent higher monthly payments on housing. During the same period average interest rates on new mortgages rose about $11 / 4$ percentage points, resulting in about 12.5 per cent higher monthly payments on a 25-year loan. However, this increase in interest rates took place mainly in periods of rapid money expansion and may come back down after excessive demands and inflationary pressures are eliminated. The higher cost of housing as a result of inflation is not likely to be reduced by much.

6The higher construction costs may be offset only partly by a rise in the expected future resale value of the house. 


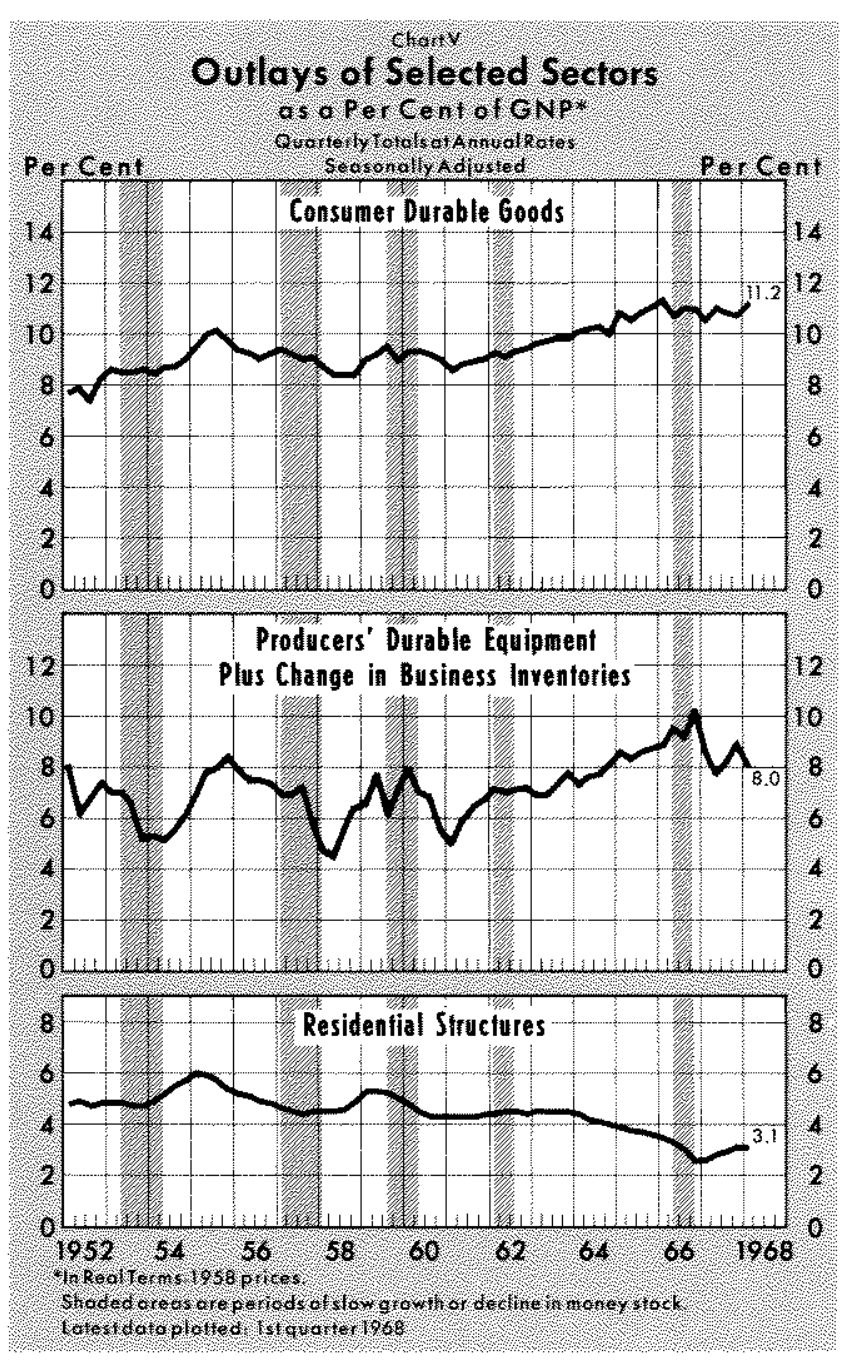

\section{Shower Honetary Growh and Other Sectors of we Wconomy}

\section{Consumer and Business}

Although monetary restraint may affect the total real dollars spent on housing, the housing sector is not the only one to feel a monetary squeeze. Chart $V$ shows two other sectors plotted along with residential construction: (1) outlays on consumer durable goods, such as automobiles, appliances, and furniture, and (2) expenditures on business machines and other producers' derable equipment plus changes in business inventories. Each sector is plotted as a percentage of real GNP to relate the effect on it to the effect on over-all activity.

Both consumer durable goods and producers' durable equipment have had a slight upward trend relative to total production since 1951, while residential construction has trended downward; yet the formers declines or slower rates of increases during periods of slow money growth have been roughly equal to those in the latter. Also, declines in the other two sectors sometimes actually began during the periods of slow monetary expansion. It appears that housing has not been any more adversely affected during periods of relatively slow monetary growth than have these other sectors.

\section{Construction Employment}

Monetary restraint does not appear to bear unduly on construction workers. Although an initial move toward slower monetary growth has temporarily reinforced a decline in the housing sector, the evidence suggests that most workers in residential construction have not been at an increased disadvantage in finding jobs. Unemployment among construction workers typically is higher than unemployment generally, as can be noted in Chart VI. From the chart it is evident that periods of slower monetary growth usually did not affect construction workers much more than they did workers in other activities. Unemploym ment in this industry rose at times in the first few months of the restrictive period, but, in general, the relative unemployment of construction workers changed little during periods of monetary restraint. Construction workers, being relatively mobile and skilled, may have been better able to find jobs than were others with less skill and mobility.

\section{Contractors}

The experience of contractors has been similar. Chart VII plots failures of construction firms as a

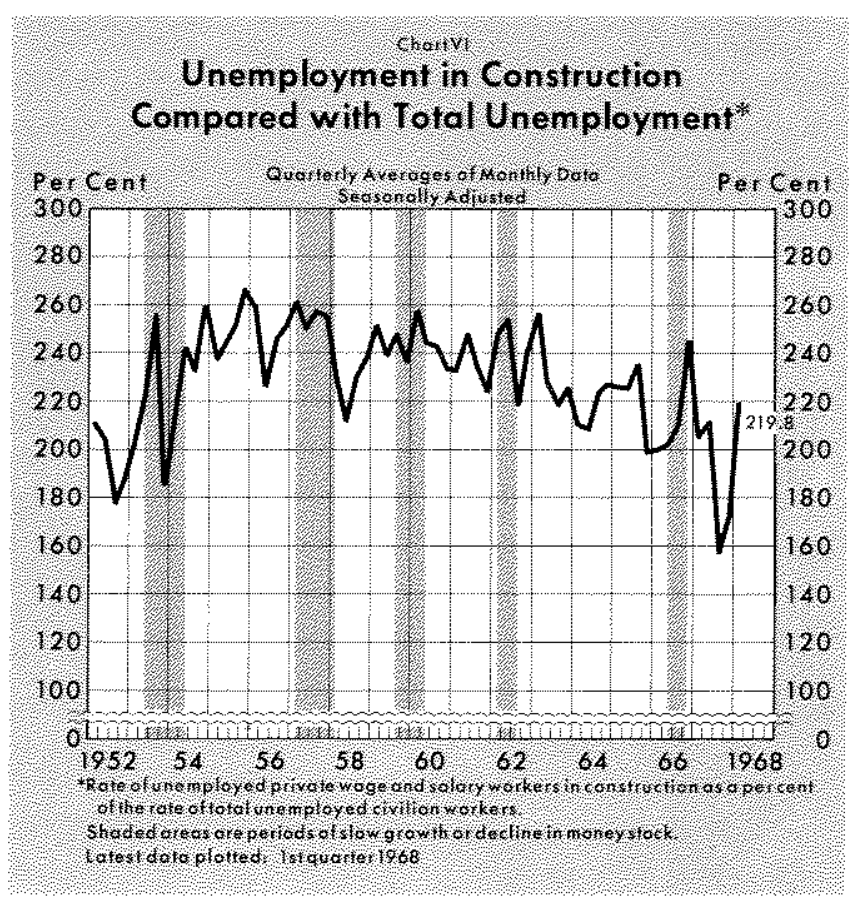




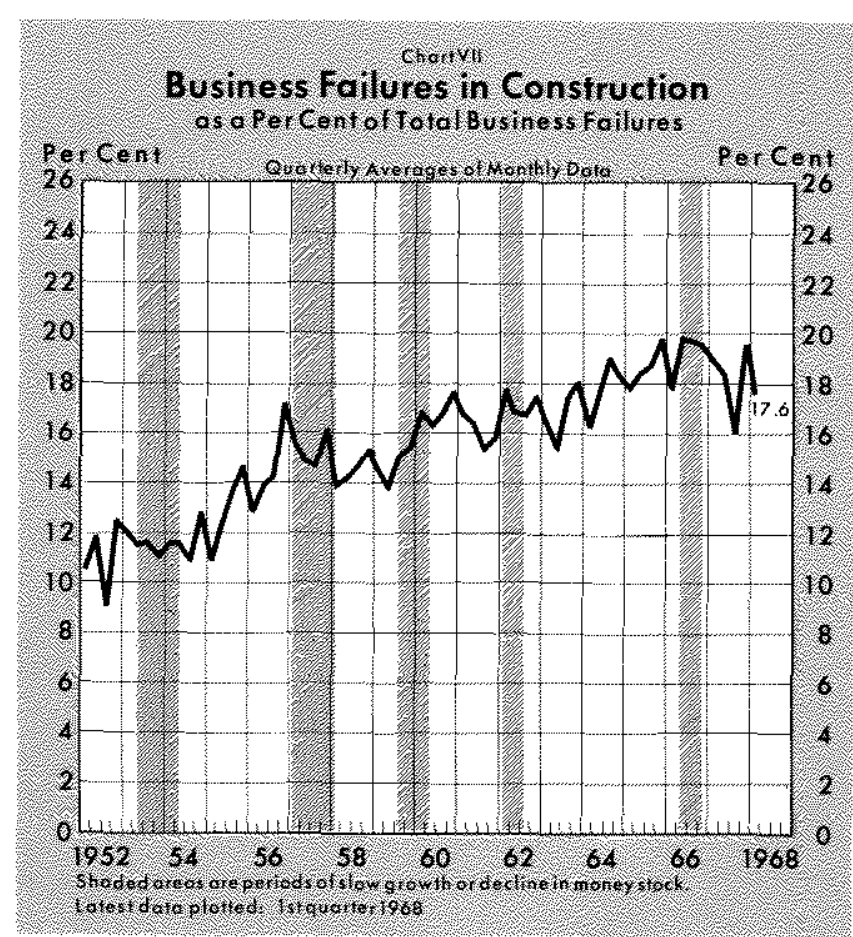

per cent of total business failures. Although there has been an upward trend in failures of construction firms relative to other businesses, their relative position improved temporarily in four out of the five cases of monetary restraint since 1951. The one exception was the 1959-1960 period.

The upward trend in construction failures may have reflected the uptrend in interest rates resulting from excessive total demands and inflation. Then, too, it may have been partially a reaction to some overbuilding in the fifties. The relatively small size of most contractors, perpetuated in part by zoning laws and building ordinances, may have made the industry less viable. A bigger enterprise with more capital and reserves more easily could aocept temporary losses and changes in the economy. A part of the hardships suffered by contractors, as well as a factor tending to discourage large amounts of capital from coming into the industry, may be associated with those regulations which the same concerns use to gain temporary advantages.

\section{Financial Intermediaries}

Restrictive monetary actions may have an effect on housing by affecting adversely the flow of funds into financial intermediaries which extend most of the housing credit. Yet, a review of some measures of industry performance does not indicate that financial intermediaries are any more severely affected by a relatively slow rate of monetary expansion than is business in general. A chief intermediary is the savings and loan associations. Chart VIII shows yearly profits of all savings and loan intitutions since 1951 and yearly iates of change of profits. A striking feature of the chart is that since 1951 savings and loan companies in the aggregate have had increased absolute profits each year. Also, during periods of monetary restraint profits grew at an expanding rate, except in the 1966 period when a trend toward a slower rate of increase already had begun.

From 1952 to 1966 profits of savings and loan companies rose at a 16 per cent average annual rate, and in 1966 they went up 7.3 per cent. Mutual savings banks had similar results. Their net income grew at an 11 per cent average rate between 1953 and 1966, and 10 per cent during 1966.

Profits of a mutual association may not be comparable with earnings of other firms which deduct the cost of obtaining funds as an expense. But, even if the cost of attracting share accounts (i.e., dividends) is deducted from profits, the remaining additions to reserves have been sizeable each year since 1952 . Even in the adverse year of 1966, savings and loan associations were able to add $\$ 600$ million to their

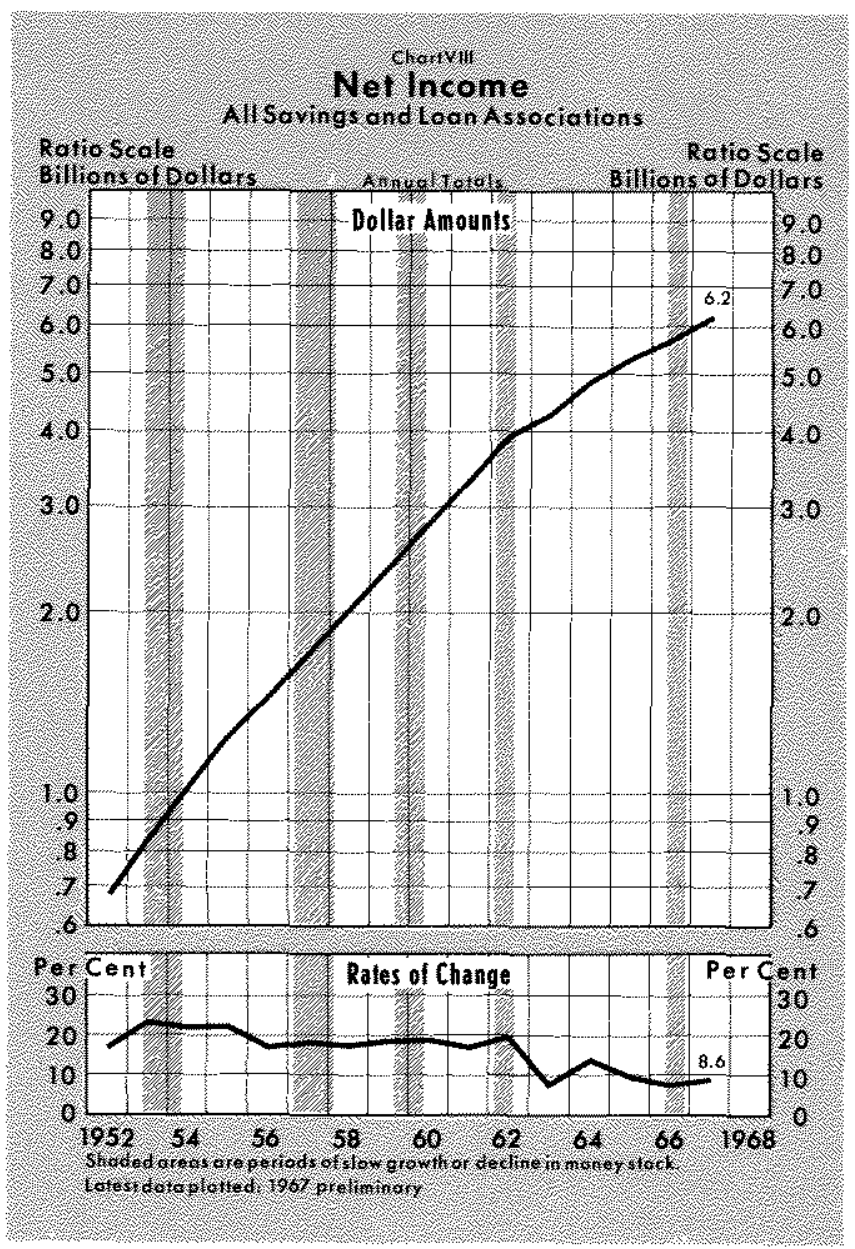


reserves, and the ratio of reserves to total savings balances rose from 7.90 per cent to 8.18 per cent.

Savings and loan associations have been hindered temporarily during periods of slow monetary growth in securing savings. There have been several setbacks in the rate of increase in savings capital of these institutions during periods of monetary restraint, and for one quarter (third quarter 1966) there was a moderate net decline (Chart IX). Rising interest rates make yields on savings accounts, which are regulated by FHL, "rate controls", relatively less attractive than rates paid in the free market. To a great extent the real problem has been not in the rising market interest rates, but in rate controls on the savings and loan associations. Nevertheless, despite all the market imperfections, increases in net savings funds in savings and loan associations have been at an average 13,6 per cent annual rate since 1952 ; in the most adverse year -1966 - they rose 4 per cent. Similarly, deposits in mutual savings banks increased at a 7 per cent average annual rate in the 1952-1966 period and 5 per cent during 1966 .

Financial intermediaries perform an economic function by borrowing short-term funds and lending them for long terms. Therefore, a sharp unexpected rise in the market interest rate structure puts them at a temporary disadvantage. To compete for funds to make new loans and provide for withdrawals, they messt raise interest rate payments on all their outstanding deposits, ${ }^{7}$ but yields on their assets are fixed. As a result, expenses rise much more rapidly than earnings in the short run. Because of this situation, some feel that a rapid rise in market interest rates accompanied by higher rates paid by intermediaries may cause a general collapse of these financial institutions. It is partially for this reason that interest rates paid by financial intermediaries are regulated.

Although an industry that borrows short and lends long may incur losses for a period when interest rates rise sharply, most financial intermediaries have considerable ability to withstand these temporary periods when their terms of trade are adverse. In addition to their own resources, savings and loan associations and mutual savings banks may borrow from Federal Home Loan Banks.

For example, the book value of aggregate reserves and undivided profits of savings and loan institutions is nearly twice the size of their yearly dividend pay-

\footnotetext{
There are exceptions, of course, such as paying higher rates on certificates or for funds left for a longer period.
}

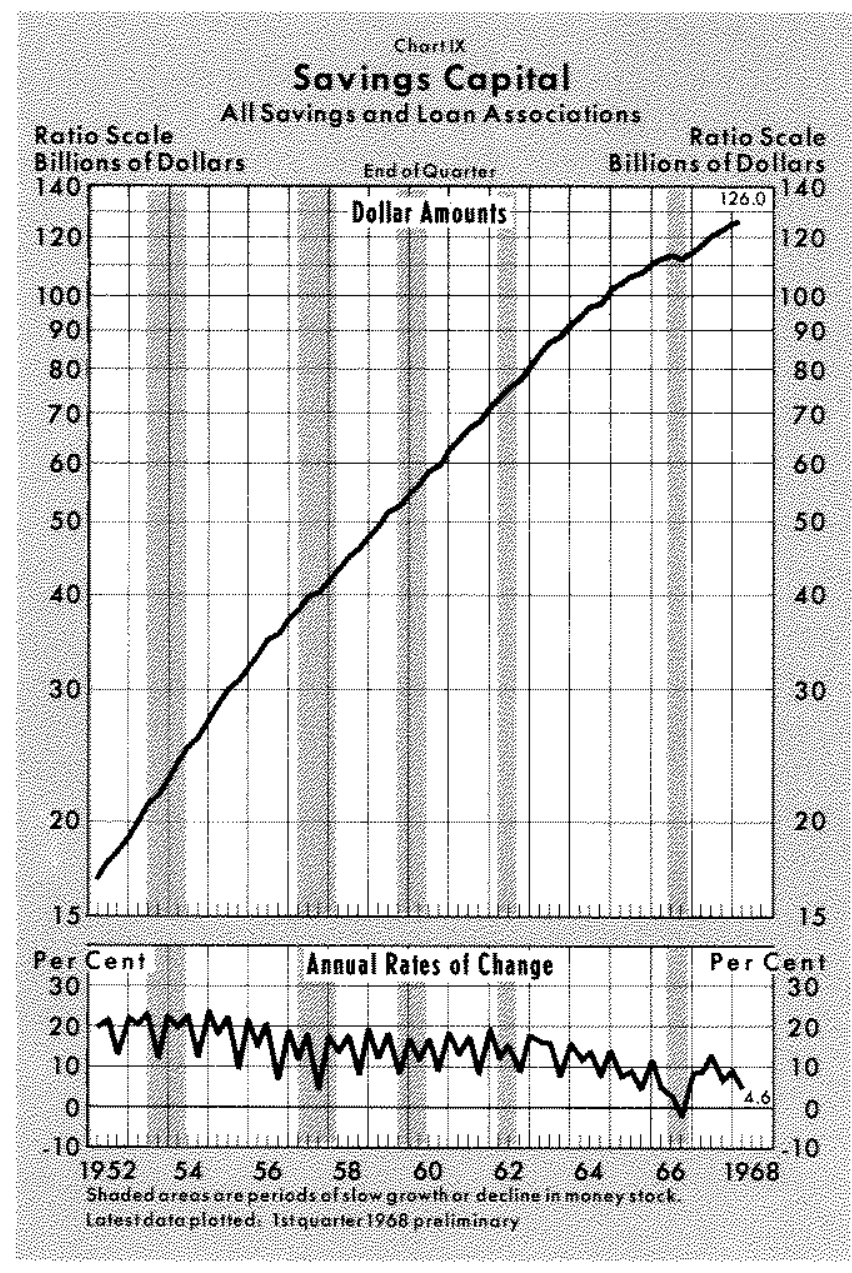

ments. They also have cash and Government security holdings from which payments could be made totaling over double their yearly dividend payments. These ratios prevailed even at the end of 1966, after the associations had endured their most adverse year. This means that the average association could remain solvent in an accounting sense and pay its dividends for nearly two years, even though it had no net profits. Yet, in every year since World War II, these associations have had greater profits than in the previous year.

Also, throughout the period of rising interest rates, greater returns will be flowing in from the loans made at the higher rates; in 1967, for example, repayments of regular instalments, interest, and advance repayments because of house sales amounted to about 15 per cent of average total outstanding mortgages at savings and loan associations. Even more important, periods of monetary restraint rarely have lasted even a year in length, and after a few months of slower monetary growth interest rates have had a tendency to come down. 


\section{Conerionsions}

This analysis is tentative; a complete study would require an examination of the data presented in much more detail, as well as additional evidence bearing on the subject of discriminatory effects of monetary policy. Nevertheless, it appears from the information thus far developed that the requirements of the housing industry should not act as a constraint on monetary policy designed for the general welfare.

In this analysis, periods of extreme monetary restraint were studied. With the advantage of hindsight, it now appears that in most of these periods monetary actions were unduly restrictive, since all economic recessions since 1952 commenced during these periods. Housing was affected during periods of slow monetary growth, particularly in the first few months, but indications are that the housing industry was affected little more than was activity in general throughout all the periods of restraint. The widespread belief that housing has been seriously hurt by monetary restraint probably has resulted from mistakenly identifying rising market interest rates with monetary restraint. Interest rates, unadjusted for price developments and for Govermment borrowing, and unrelated to changing profit expectations of businesses, are usually a poor guide to either the rate of monetary expansion or its impact on economic activity.

Conversely, the evidence is strong that housing is seriously affected by excessive total demand for goods and services and inflation. Not only do the excesses drive up the costs of constructing houses, but these huge demands and the inflationary pressures push up market interest rates, which tend to bear heavily on the housing industry.

Little evidence has been found to indicate that the housing industry or the financial intermediaries are affected in such a manner which makes them gain from excessive monetary expansion. It seems that they, as most other sectors, flourish best in an economy growing at a relatively steady rate without inflation. The housing industry might be benefited, however, by a repeal or a liberalization of laws, regulations, and practices that interfere with the free flow of funds from the saver to the ultimate borrower.

NORMAN N. BOWSHER

LIONEL KALISH

This article is available as reprint series No. 29.

SUBSCRIPTIONS to this bank's REviEw are available to the public without charge, including bulk mailings to banks, business organizations, educational institutions, and others. For information write; Research Department, Federal Reserve Bank of St, Lotis, P. O. Box 442, St. Louis, Missouri 63166. 